\title{
Swalayan Upakara Bali: When Tradition Meets Technology (The Resilience of Balinese Rural Women in Digital Era)
}

\author{
Ni Made Tisnawati ${ }^{1}$, Khusnul Ashar ${ }^{2}$, Devanto S. Pratomo ${ }^{3}$, Susilo $^{4}$ \\ \{nimadetisnawati@unud.ac.id ${ }^{1}$,khusnul_ashar@yahoo.co.id², devanto@ub.ac.id ${ }^{3}$,susilo@ub.ac.id ${ }^{4}$ \} \\ Universitas Udayana, Indonesia ${ }^{1}$ \\ Universitas Brawijaya, Indonesia ${ }^{1,2,3,4}$
}

\begin{abstract}
Most of rural women in Bali Province are informal sector workers who can be classified as vulnerable workers due to their socioeconomic conditions. They are also less likely to escape from poverty. Additionally, their traditional role in preserving cultural traditions as the basic asset of Bali's tourism has put more burden on them. These conditions are likely more evident in Gianyar Regency that has the second most temples and the highest frequency of traditional ceremonies in Bali Province. Because rural women in Gianyar Regency have to allocate a significant portion of their time to prepare traditional ceremonies, they become less reliable informal workers. In this respect, buying ceremonial materials in traditional markets is their resilience strategy by becoming both producers and consumers. This study examines how rural women develop their resilience strategy when they are confronted with modern, large-scale firms that offer similar ceremonial (Upakara) materials and the advancement of the digital era. This research uses a qualitative approach with a case study in Gianyar Regency, Bali Province. The findings show that rural women who have digital access can actively utilize the marketplace and social media to increase their economic resilience. Some marketplaces such as "Swalayan Upakara Bali" help rural women survive. Conversely, women who do not have digital access only survive in traditional markets. This study contributes to the empirical literature on women's work participation as a form of economic resilience and also on economic sociology especially the resilience of Balinese rural women in participating in economic activities and, at the same time fulfilling traditional responsibilities to preserve their cultural traditions.
\end{abstract}

Keywords: Resilience, Rural Women, Traditional Religious Ceremonies, Digital Era, Traditional Market.

\section{Introduction}

Balinese women have a very adaptive resilience to external pressures. Historical records indicate that since 1920, Balinese women have resisted the oppression of women. Led by educated Balinese women residing in Java, the struggle established various social organizations such as Poetri Bali Sadar. The abilities of these women enabled them to release other women from poverty through free education and skills training. In 1936, the exploitation of women's image for tourism purposes was even opposed by the protest movements through writing. In 1950, Balinese women again protested in the Bhakti and Peace magazines in Denpasar [1]. Nowadays, Balinese women are confronted with the swift flow of internet technology. Also, they have to carry out the obligation to preserve Balinese ceremonial traditions together with 
the obligation to carry out economic activities in the informal sector. These facts lead to the following research question: how do women's resilience behavior use the digital era to survive economic activities while preserving Balinese culture?

Any economic growth process that fails to improve the welfare of the most vulnerable population, especially women and children, basically fails to achieve its main goals. If women's welfare or education is still neglected, then their children will also likely suffer, and eventually, the whole population will suffer because children are the future of a nation. Thus, human resource investment will be more productive if it also focuses on improving women's status and welfare. Because human resources are one of the most important requirements for sustainable growth, education, and other efforts to improve women's welfare and economic status are important to achieve various long-term development objectives [2].

The neo-classical theory [3] argues that individuals or household members enter the job market because they expect more income and benefits from working besides economic activity. They then allocate their time to work and leisure time. Thus, this theory is commonly known as income-leisure theory. However, the underutilization of female workers affects economic growth and well-being. It is difficult to measure the work participation of women, especially unpaid worker ones. The difficulty is likely due to the measurement system that does not acknowledge women's contribution to the economy for cultural reasons.

The income-leisure model identifies the labor supply with wage and income. Non-economic considerations are considered exogenous variables. The decision to work depends on the wage rate and non-labor income. In this respect, wage has ambiguous impact (increases or decreases) job participation. Also, non-labor income has a significantly negative influence on job participation.

Some empirical studies suggest that non-economic variables, such as marital status, urbanization, land tenure, family head status, labor structure, affect work participation. Also, working women's behavior is affected by their characteristics (such as income, demographics such as age and birth rate, religion, and education). Further, religion negatively affects women's work participation. For example, Hindu-majority countries exhibit more than $40 \%$ of lower women's work participation.

ILO shows several indicators that measure women's work participation, such as work participation rate, wage rate, and so on. Women allocate more of their time to non-economic activities. Several factors motivate women to enter the job market, including postnatal health conditions, childbirth, government policies on family care benefits, technologies that help women in economic activities, social and cultural norms affecting women's economic activities, and structural economic changes. In this respect, the relationship between GDP and women's participation rate forms a U-shape. Within the agrarian economic structure, some of the workforces are women. As technology advances, the number of working women increases, especially after the measurement of GNP is upgraded. Also, more opportunities for obtaining education make women more educated and increase the opportunity cost of women's domestic activities. Consequently, women's participation in economic activities increases.

Various women's internal and external factors make women's participation low. Nwihim (1983) and Tadesse (1984) in [4] mention that women's roles are neglected in economic development. One of the most serious problems in the female labor force statistics is that many female workers are not incorporated in the economy that causes women's participation in economic development to be underrepresented.

ILO [5] finds that in Indonesia, vulnerable workers are employers assisted by permanent workers, freelancers, independent workers, and unhired family workers. These vulnerable 
workers comprise 57.6 percent of the total workforce. However, the proportion of vulnerable female workers to total female workers is higher (61.8 percent) than that of men (54.9 percent).

Referring to Poffenberger et al. [6], Gianyar Regency is one of the areas with the most frequent Upakara ceremonies in Bali Province. Consequently, women choose to work in the informal sector to earn income and support their families' economy. This study also reveals that Balinese women manage to perform two or even three jobs at once while still observe ceremonial activities. Women in Gianyar Regency use their informal works as their strategy to demonstrate their contributions to increase their families' income. BPS [7] also shows that Gianyar Regency has the most temples or places of worship in Bali after Tabanan Regency (788 temples). A large number of temples indicate that the great responsibility of women in this regency to organize ceremonies routinely that comply with Balinese beliefs and culture.

The high proportion of time to be allocated for preparing ceremonies by Balinese women in Gianyar Regency requires skillful adaptation by rural women. Because women prepare ceremonial materials from traditional markets, the existence of these markets that sell Upakara materials (Upakara Yadnya market) - especially in rural areas - greatly affects women's work participation in the informal sector. In traditional markets, women can act as both producers and consumers. They can also advise their colleagues on ceremony preparations to preserve their culture. Although they can make ceremonial materials by themselves, they can buy the materials in traditional markets.

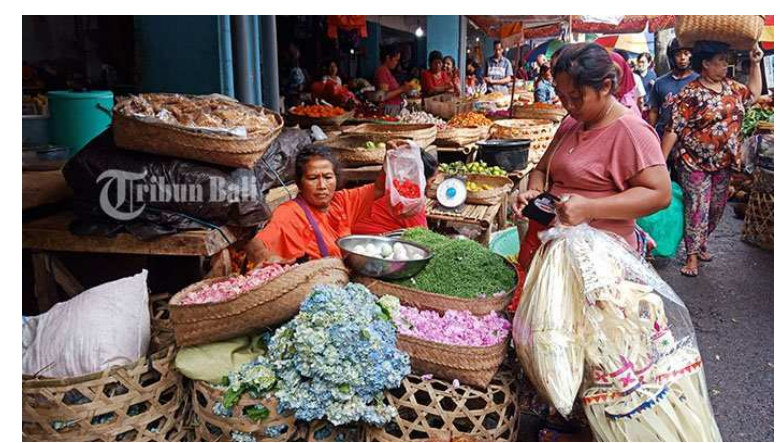

Fig. 1. Balinese Rural Women and Traditional Market

Figure 1 shows a traditional market that sells materials and tools to make Upakara Yadnya. These materials and tools are made of agricultural products (janur or greenish-yellow coconut leaves, leaves, fruits), and home industry products (Bali pandan mats, woven ate or rattan-made bags). It is common that in these traditional markets, female informal workers sell certain Upakara-making services to both female formal and informal workers who choose to allocate more time for seeking additional income than for preparing their own Upakara. Women's domination in the trading sector in traditional markets is crucial for rural women's work participation in Gianyar Regency. Thus, the trading sector allows women in rural areas with a low formal education to earn income.

Because Gianyar Regency has the highest frequency of Upakara ceremonies in Bali Province, the presence of the Yadnya markets in its rural areas is vital for the livelihood strategy of rural women. Further, the provision of Upakara-making services in the Yadnya markets by women in rural areas also support agricultural products produced by other women workers in the agricultural sector. Meanwhile, female workers have to allocate more of their time to work, and consequently, they cannot fulfill their obligations to prepare Upakara at their houses or traditional villages. In this case, they can become consumers in the traditional markets that sell 
Upakara materials. Thus, a distribution pattern between women who work in the informal sector as the producers of Upakara materials and women who work in the formal or informal sector with limited time as consumers.

However, the Yadnya markets have been recently threatened by the presence of large-scale competitors that are more efficient and consequently manage to offer cheaper products. In particular, as can be seen in Figure 2, some supermarkets in Gianyar Regency has begun to sell Upakara tools. Additionally, the traditional markets that sell Upakara materials also have to compete with other competitors due to the advances of information technology-based ecommerce.

Traditional markets play a crucial role in enhancing rural women's work participation in Gianyar Regency because women can dominate economically in these places. Thus, the trading sector allows rural women with a low formal education to earn income.

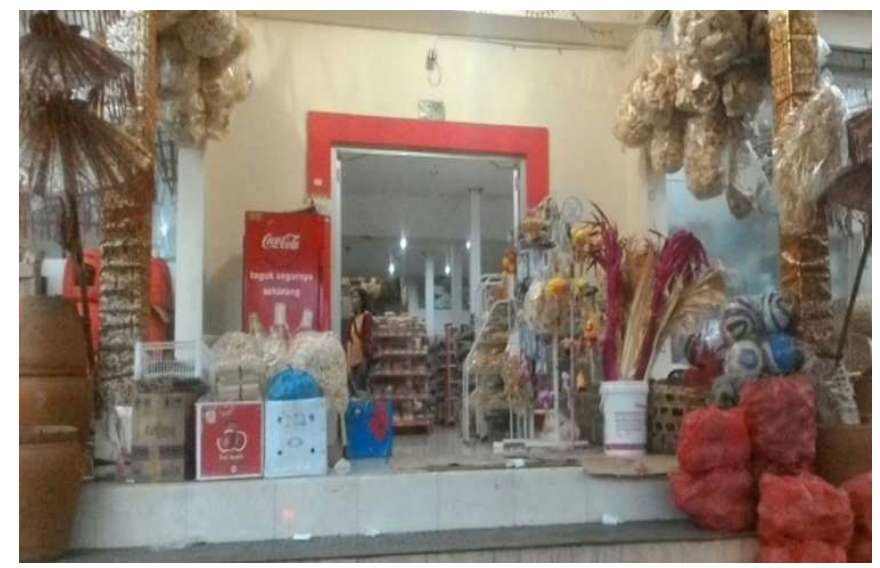

Fig. 2. Upakara in Supermarket: A Threat to the Traditional Markets?

These supermarkets are also located in several rural areas in Batubulan and Singapadu, Gianyar. The owners of these supermarkets likely identify the high demand for Upakara materials and tools, as indicated by the presence of technologically more advanced and more efficient firms that threaten small household firms. Consequently, traditional markets as the popular art markets begin to lose their customers due to the presence of supermarkets that sell similar products but at lower prices.

The high demand for Upakara and Upakara materials is not only fulfilled by traditional markets and Upakara shops. Technological advances and a growing segment of female consumers who work in the formal sector with time constraints motivate some women in the informal sector to sell Upakara materials through e-commerce channels. They upload their creative Upakara material products, or even their skills in preparing Upakara into social media such as Facebook, Instagram, or Whatsapp. Some even upload simple tutorials on how to prepare simple Upakara into Youtube. Thus, technology turns out to be one of the survival strategies of female informal workers to earn revenues amid the competition that sells similar products. Resilience is the process of effectively negotiating, adapting to, or managing significant sources of stress or trauma. Individuals' assets and resources, life, and environment enable them to adapt to and "bounce back" adversities in their life. Consequently, individuals will have different experiences of resilience [8]. Another study also defines resilience as a "process to harness resources to sustain well-being". Several factors affect resilience, such as 
personality, specific challenges, resources available, environmental context, age, and individual maturity. Environmental resilience dependence requires the self-understanding of individuals, families, and the environment in which individuals manage to determine precisely their resilience strategies [9]. This study asks the following questions: (1) What is the resilience strategy of rural women who do not have digital access to sustain its economic activities? (2) How do new technologies inform the resilience of Balinese Rural women in Gianyar Regency? (3) What are the most effective ways to enhance the resilience of Balinese rural women in Gianyar Regency?

\section{Research Methods}

This study is a qualitative approach. We collect the data by documenting women's social media, especially those that are related to the use of technology to preserve ceremonial traditions and women's market activities as both producers and consumers of Upakara materials. In particular, we observe the Facebook groups of Balinese women and the Upakara tradition. Further, to investigate the resilience strategy of women who do not have internet access, this study randomly distributes questionnaires to 50 female informal workers whose economic activities are related to traditional markets. This study also identifies respondents' socioeconomic characteristics and motivation to analyze their resilience strategy to participate in economic activities and ceremonial traditions simultaneously.

\section{Results and Discussion}

The digital age turns out to provide a resilience strategy for rural women to continue working in the informal sector amid rapid technological advance and the responsibility of carrying out ceremonies. Some rural women gather themselves in social media groups. Group themes generally have something to do with how to make ceremony offerings.

Table 1. Balinese Women's Facebook Group on the Preservation of Upakara Ceremony

\begin{tabular}{|c|c|c|c|c|}
\hline No & Name of Group & $\begin{array}{c}\text { Year of } \\
\text { establishment }\end{array}$ & $\begin{array}{c}\text { Number of } \\
\text { Members }\end{array}$ & Content \\
\hline \multirow[t]{2}{*}{1} & $\begin{array}{l}\text { Swalayan Upakara } \\
\text { Bali.com }\end{array}$ & 2017 & 14,909 & $\begin{array}{ll}\text { On-line } & \text { ceremony } \\
\text { transactions } & \end{array}$ \\
\hline & & & & $\begin{array}{l}\text { Discussion of ceremony } \\
\text { series }\end{array}$ \\
\hline 2 & Belajar Banten Bali & $\begin{array}{l}\text { May 23, } \\
2016\end{array}$ & 46,547 & $\begin{array}{l}\text { Simple tutorial on how to } \\
\text { make simple Upakara }\end{array}$ \\
\hline 3 & $\begin{array}{l}\text { Belajar Banten Bali } \\
\text { (Tabanan) }\end{array}$ & $\begin{array}{l}\text { January } 3, \\
2018\end{array}$ & 26,334 & Procedures to create Banten \\
\hline 4 & $\begin{array}{l}\text { Tetandingan Banten } \\
\text { Bali }\end{array}$ & 2018 & 7,428 & Cultural community website \\
\hline 5 & $\begin{array}{l}\text { Mesari Yadnya } \\
\text { (Karangasem) }\end{array}$ & 2018 & 1.058 & $\begin{array}{l}\text { Online } \\
\text { transactions }\end{array}$ \\
\hline
\end{tabular}


$7 \quad$ Halo Pejati

8 Wanita Bali Mandiri (Banten and Sampian Bali)

9 Swalayan Banten Bali (Singaraja)

10 Banten Hindu Bali (Batubulan)

\section{August 18, 2016

December 2, 2017

2018

2017
43,617

(1)

280

5,643

Study of Balinese ceremonies based on literature and philosophy

Ceremony transactions

Discussions about Hindu life and rituals

Learning to make Banten, cooperation forum

Sale of Banten special
ceremony in Buleleng
regency
Banten buy-and-sell forum

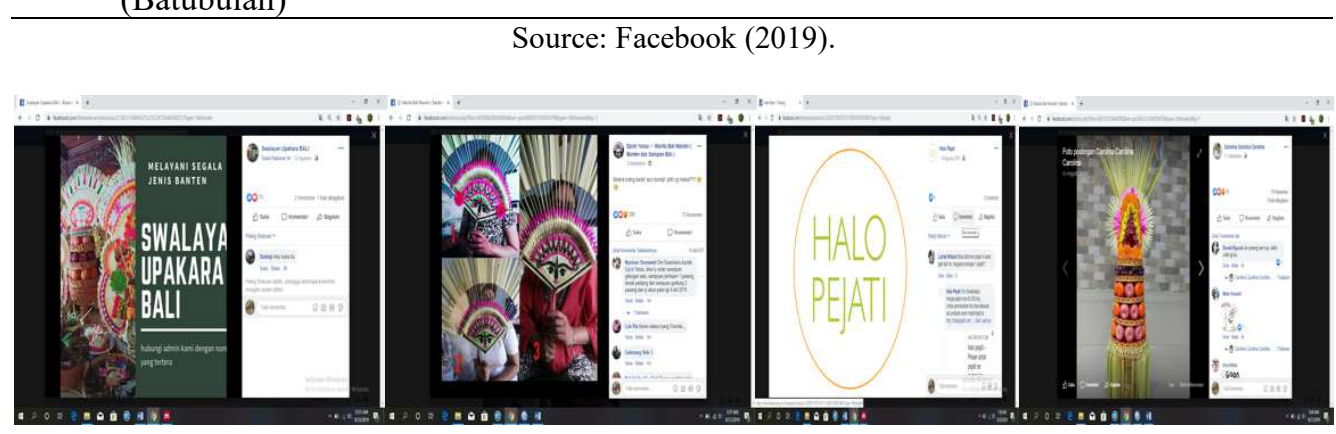

Fig. 3. Balinese Women's Activities on Social Media

Some Facebook groups in Table 1, such as Banten Hindu Bali, Halo Pejati, Supermarket Upakara Bali, Supermarket Banten Bali, involve women's economic transactions of Upakara materials. The admins of these groups even explicitly indicate the package prices of these materials. For example, the offered price of the simplest Upakara materials (Pejati) is Rp 40,000. Likewise, they also offer other Upakara materials which women need in their households such as Pengulapan, Prascita. Technological advances significantly facilitate women to have greater access to Upakara materials through online channels. For instance, they can upload the examples of their Upakara materials they produce together with the offered prices and delivery services through the internet, implying that online markets offer a solution for women who aim to enhance their work participation while at the same time still observe their responsibilities to preserve cultural traditions by organizing ceremonies.

A self-service Facebook account, Upakara Bali, sells Upakara packages at very low prices. The account initiators aim to make their Facebook account an online place that enables women to find affordable Upakara packages without compromising the meaning of the offerings. It also offers a variety of other ceremonial packages, from Bhuta Yadnya to the deity Yadnya like Ngaben (cremation ceremony), at the lowest prices. For example, the cost of Ngaben is offered as low as Rp 3 million. Indeed, the basis of these service offerings is a sincere spirit to help others organize Upakara because ceremonial traditions often impose responsibilities on women's households in rural areas, especially in economic terms. Further, the passion for helping fellow Hindu women motivates Jero Mangku Veni to found Dharma Ayu Yandnya 
through the Facebook account of Banten Hindu Bali. The high demands, especially from working women, lead to rapidly growing Upakara offerings.

Unexperienced women who aim to make their Upakara materials can consult the Facebook account of Belajar Banten Bali or self-reliant Balinese women. Women create hundreds of tutorial videos presenting simply on how to make Upakara from the simplest form to the most complicated one. Thus, some Balinese women can utilize technology positively to cope with the demands to increase their work participation and, at the same time, preserve the traditions by observing ceremonies.

These social media groups significantly increase online market opportunities for Upakara materials sellers. Without a lot of capital, women can create very strategic job opportunities because of the increasingly high demand for Upakara materials. For example, the creators of the self-service Facebook account of Upakara Bali that sells Upakara packages at very low prices seek to sell affordable Upakara materials without compromising the meaning of the offerings. Also, various other ceremonial packages from Bhuta Yadnya to the deity Yadnya like Ngaben Nista are offered at low prices. Ngaben, for instance, is offered at Rp 3 million. The creation of this account is motivated by the sincere spirit to help others not burden themselves in organizing Upakara. Because some ceremonial traditions often impose responsibilities on women's households in rural areas, especially in terms of economics, we then propose a question on how women who lack access to the internet technology respond to the demands to observe the ceremonial traditions.

To investigate how rural women who do not access the internet cope with the demand, these study interviews 50 randomly selected rural female respondents in Ubud Sub-district, Gianyar, Sukawati, the Payangan District of Gianyar Regency, Bali Province. Ceremonial traditions that require a significant portion of rural women's time do not make these women lose their economic activities.

Several women work formally and have limited time to acquire ceremonial materials. This condition allows women who work informally to meet the needs of the ceremonial materials more efficiently. Thus, the traditional markets become a hub between formal female workers who have limited time to prepare Upakara as the consumers and women who work in the informal sector as the producers. The high demand for Upakara materials in the traditional markets offers huge opportunities for women in the informal sector. A unique feature of each traditional market in Gianyar Regency is that these women rely on kinship to acquire villagewide information on consumers. For example, female sellers of Upakara materials at a market in Ubud district will have different characteristics than female sellers in Sukawati district likely because of different ceremonies, different requirements of these ceremonies. 


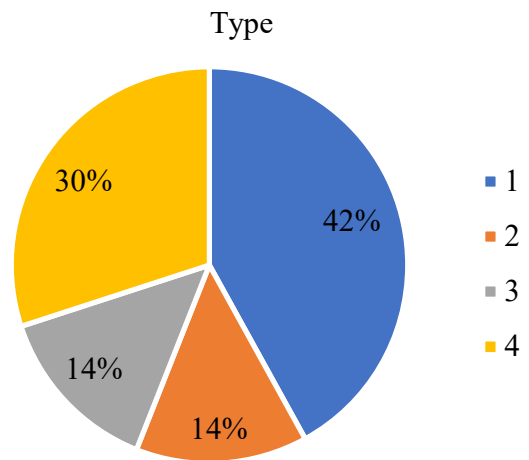

Fig. 4. The composition of women's roles in the traditional markets (Primary data, 2019).

Based on their economic activities in the traditional markets, our respondents are largely (42\%) sellers. In particular, they sell various Upakara materials such as janur, flowers, fruits, beans, coconuts, eggs, and special cakes. Next, only $14 \%$ of our respondents produce Upakara materials. The other $14 \%$ are both producers and sellers of Upakara materials. Lastly, $30 \%$ of the respondents prepare Upakara materials.

Based on the formal educational level, the majority of the respondents (48\%) only completed elementary education. Meanwhile, $14 \%$ of the respondent finished junior high school, and $36 \%$ completed their senior high school. There are about $2 \%$ of the respondents who did not complete their primary education. Based on their age, most respondents (42\%) are 40-49 years old, followed by those who are 50-59 years old (24\%), respondents who are 30-39 years old (12\%), and those who are $60-69$ years old $(12 \%)$. There are also notable respondents $(8 \%)$ who are more than 70 years old.

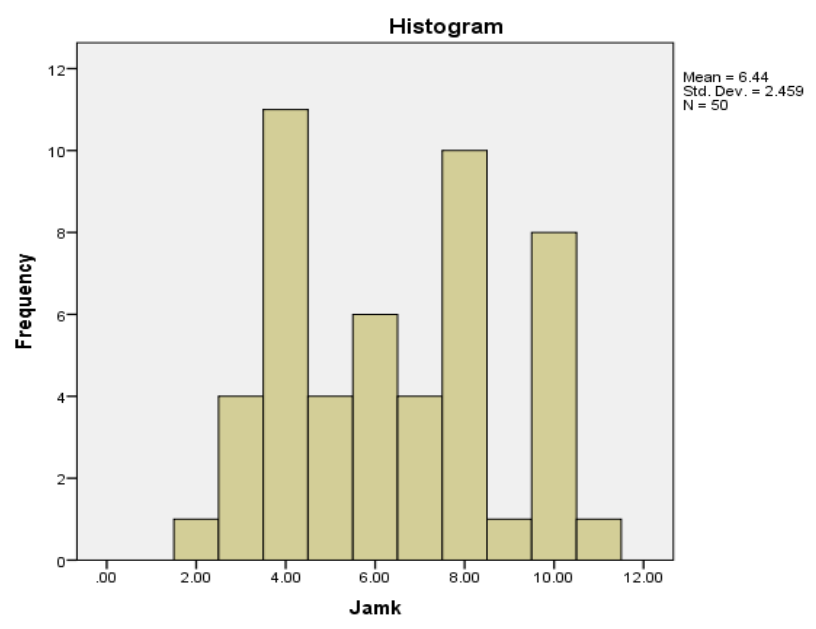

Fig. 5. Respondents by working hours (Primary data, 2019).

About $40 \%$ of the respondents work full-time ( 8 hours a day), and even $2 \%$ of the respondents work 11 hours a day due to multiple works. The rest of the respondents $(60 \%)$ do not work full-time, and most of them (22\%) only work 4 hours a day. 
Women with limited internet access still manage to survive in the traditional markets despite their capabilities and households' conditions. Some women even work two or three jobs at once in a day. These rural women face various problems such as low education level, no internet access, and capital constraints. However, they still can cope with various responsibilities imposed on them, such as preserving cultural traditions, being family breadwinners, and performing domestic household duties.

As producers of ceremonial materials, rural women need to utilize internet technology to promote their skills and expertise to more consumers in Bali Province. The high demand for ceremonial materials offers huge opportunities for rural women in the informal sector to increase their revenues. At the same time, women who work in the formal sector are better able to focus on increasing their professionalism because they can prepare traditional ceremonies at their households more efficiently. However, these rural women's economic opportunities must be protected from large-scale investors who have started their operations in the Sukawati district recently. In this respect, technology offers a solution to do so.

\section{Conclusion}

This study demonstrates that women with better internet access are better able to fulfill the market demand for Upakara materials. However, rural women who do not have internet access can still survive in the traditional markets despite their limitations. It is necessary to develop a strategy to connect rural women's skills in producing Upakara materials in the traditional markets with women who sell Upakara materials through online marketplaces. Such collaboration will likely mitigate the threats of large investors who start to penetrate the traditional markets. This study suggests future studies to investigate further Balinese women's behavior in their economic activities during the recent digital revolution.

\section{References}

[1] D. Putra and I. Nyoman, Wanita Bali Tempo Doeloe Perspektif Masa Kini. Bali Jani. 2003.

[2] P. Todaro Michael and B. Abdullah, "Pembangunan Ekonomi Dunia Ketiga," Jakarta: Penerbit Erlangga, 1998.

[3] G. Psacharopoulos and Z. Tzannatos, "Female Labor Force Participation: An International Perspective," vol. 2, no. 2, 1989.

[4] C. . Omari, "Rural Women, Informal Sector and Household Economy in Tanzania. Wider working papers World Institute for Development Economics Research of the United Nations University, Helsinki," 1988.

[5] ILO, Laporan Ketenagakerjaan Indonesia 2017: Memanfaatkan Teknologi untuk Pertumbuhan dan Penciptaan Lapangan Kerja. Organisasi Perburuhan Internasional, Kantor Jakarta. 2017.

[6] Poffenberger, M. dan Zurbuchen, and M. S, "The Economic of Village Bali: Three Perspective. Economic Development and Cultural Change," 1980. [Online]. Available: http: www.researchgate.net/publication/24097175.

[7] BPS, Statistik Ketenagakerjaan Kabupaten Gianyar Tahun 2017. 2018.

[8] G. Windle, "What is resilience? A review and concept analysis," Rev. Clin. Gerontol., vol. 21, no. 2 , pp. 152-169, 2011.

[9] L. Briguglio and C. Gordon, Economic Vulnerability and Resilience: Concepts and Measurement. Oxford Dev. Stud, 2009. 